\title{
Pengaruh Aromaterapi Lemon terhadap Penurunan Skala Nyeri Pasien Post Operasi Laparatomi
}

\author{
El Rahmayati ${ }^{1}$, Raihan Hardiansyah ${ }^{2}$, Nurhayati ${ }^{3}$ \\ ${ }^{1,2,3}$ Jurusan Keperawatan, Politeknik Kesehatan Tanjungkarang, Indonesia \\ Email: elrahmayati@poltekkes-tjk.ac.id
}

\begin{abstract}
Effect of Lemon Aromatherapy on Decreasing the Scale of Pain in Post Patients Laparotomy Surgery. The operation 2012 in Indonesia reached 1.2 million (WHO in Sartika, 2013). Based on the National Health Data Tabulation of the Republic of Indonesia in 2009, surgical procedures occupy the 11th outline of the first 50 treatment of disease patterns in hospitals in Indonesia, which is estimated to be 32\% of which are laparotomy (RI Ministry of Health, 2009). Previous data obtained from the MOH report (2007) states that cases of laparotomy operations continued to increase, from 162 in 2005 to 983 cases in 2006 and 1,281 cases in 2007. Complications in post-laparotomy patients were severe pain, bleeding, even death. Pain management is done by pharmacological and non-pharmacological techniques. In patients who experience mild pain up to the treatment can be done with non-pharmacological techniques. Nonpharmacological actions include aromatherapy using lemon oil essence. Based on the description above, researchers are interested in conducting research. This study aims to determine. This type of quantitative method research uses a quasi-experimental design with a one group pre-test posttest design approach. Sampling techniques using accidental sampling techniques were 32 respondents. Data collection uses measurements of the Numeric Rating Scale (NRS). Statistical test using Wilcoxon signed ranked test. The results of this study concluded that there were differences in pain intensity in patients post laparotomy surgery before and after lemon aromatherapy was given with p-value 0.000 . Based on the conclusions of the results of the study, the authors suggest that hospitals can consider the use of lemon aromatherapy to treat pain in postlaparotomy patients using existing standard operating procedures.
\end{abstract}

Keywords: Lemon aromatherapy, Pain, Post laparotomy surgery

\begin{abstract}
Abstrak: Pengaruh Aromaterapi Lemon terhadap Penurunan Skala Nyeri Pasien Post Operasi Laparatomi. Tindakan operasi di Indonesia tahun 2012 mencapai 1,2 juta jiwa (WHO dalam Sartika, 2013). Data Tabulasi Nasional Departemen Kesehatan Republik Indonesia Tahun 2009, tindakan bedah urutan ke-11 dari 50 pertama penanganan pola penyakit di rumah sakit se Indonesia yang diperkirakan 32\% diantaranya merupakan tindakan bedah laparatomi (DEPKES RI, 2009). Data laporan Depkes RI (2007) menyatakan kasus operasi laparatomi terus mengalami peningkatan yaitu dari 162 pada tahun 2005 menjadi 983 kasus pada tahun 2006 dan 1.281 kasus pada tahun 2007. Komplikasi pasien post laparatomi adalah nyeri yang hebat, perdarahan, bahkan kematian. Penatalaksanaan nyeri dilakukan dengan teknik farmakologi dan non farmakologi. Pada pasien yang mengalami nyeri ringan sampai dengan untuk penanganannya dapat dilakukan dengan teknik non farmakologi. Tindakan non farmakologi diantaranya aromaterapi menggunakan aromaterapi lemon, bertujuan mengetahui pengaruh aromaterapi lemon terhadap intensitas nyeri pasien post operasi laparatomi. Jenis penelitian kuantitatif desain quasi exsperiment dengan pendekatan desain one group pre-test post-test design. Teknik pengambilan sampel dengan menggunakan teknik accidental sampling sebanyak 32 responden. Pengumpulan data menggunakan pengukuran Numeric Rating Scale (NRS). Uji statistik wilcoxon signed ranked test. Terdapat perbedaan intensitas nyeri pada pasien post operasi laparatomi sebelum dan sesudah diberikan aromaterapi lemon $p$-value 0.000. Saran agar rumah sakit dapat mempertimbangkan penggunakan aromaterapi lemon untuk menangani nyeri pada pasien post operasi laparatomi dengan menggunakan standar operasional prosedur yang ada.
\end{abstract}

Kata kunci: Aromaterapi lemon, Nyeri, Post operasi laparatomi

Operasi atau pembedahan merupakan suatu penanganan medis secara invasive yang dilakukan untuk mendiagnosa atau mengobati penyakit, injuri, atau deformitas tubuh (Nainggolan, 2013 dalam Kartawijaya, 2017). Pembedahan merupakan peristiwa komplek yang 
menegangkan, dilakukan di ruang operasi rumah sakit, terutama pembedahan mayor dilakukan dengan persiapan, prosedur dan perawatan pasca pembedahan membutuhkan waktu yang lebih lama serta pemantauan yang lebih intensif (Brunner \& Suddarth, 2002).

Berdasarkan data yang diperoleh dari World Health Organization (WHO) dalam Sartika (2013), jumlah pasien dengan tindakan operasi mencapai angka peningkatan yang sangat signifikan dari tahun ke tahun. Tercatat di tahun 2011 terdapat 140 juta pasien di seluruh rumah sakit di dunia, sedangkan pada tahun 2012 data mengalami peningkatan sebesar 148 juta jiwa. Tindakan operasi di Indonesia pada tahun 2012 mencapai 1,2 juta jiwa (WHO dalam Sartika, 2013).

Laparatomi merupakan salah satu prosedur pembedahan mayor, dengan melakukan penyayatan pada lapisan-lapisan dinding abdomen untuk mendapatkan bagian organ abdomen yang mengalami masalah (hemoragi, perforasi, kanker, dan obstruksi) (Sjamsuhidajat \& Jong, 2005). Laparatomi juga dilakukan pada kasus-kasus digestif dan kandungan seperti apendiksitis, perforasi, hernia inguinalis, kanker lambung, kanker colon dan rectum, obstruksi usus, inflamasi usus kronis, kolestisitis dan peritonitis (Sjamsuhidajat \& Jong, 2005).

Jumlah pasien dengan tindakan operasi yang semakin meningkat dari tahun ke tahun dapat mempengaruhi peningkatan komplikasi pasca operasi seperti resiko terjadinya infeksi luka operasi (ILO) dan infeksi nosokomial (Haryanti, 2013 dalam Kartawijaya, 2017). Komplikasi pada pasien post laparatomi adalah nyeri yang hebat, perdarahan, bahkan kematian (Rustianawati, 2013 dalam Kartawijaya, 2017). Pasien pasca operasi yang melakukan tirah baring terlalu lama juga dapat meningkatkan resiko terjadinya kekakuan atau penegangan otototot di seluruh tubuh, gangguan sirkulasi darah, gangguan pernafasan dan gangguan peristaltik maupun berkemih bahkan terjadinya dekubitus atau luka tekan (Nainggolan, 2013 dalam Kartawijaya 2017).

Pada pasca pembedahan (pasca operasi) pasien merasakan nyeri hebat dan $75 \%$ penderita mempunyai pengalaman yang kurang menyenangkan akibat pengelolaan nyeri yang tidak adekuat (Sutanto, 2004 dalam Purwandari dkk, 2014). Adanya luka yang menyebabkan nyeri tersebut membuat pasien merasa cemas untuk melakukan mobilisasi dini sehingga pasien cenderung untuk berbaring. Nyeri akut setelah pembedahan mayor setidak-tidaknya mempunyai fungsi fisiologis positif, berperan sebagai peringatan bahwa perawatan khusus harus dilakukan untuk mencegah trauma lebih lanjut pada daerah tersebut. Nyeri setelah pembedahan normalnya dapat diramalkan hanya terjadi dalam durasi yang terbatas, lebih singkat dari waktu yang diperlukan untuk perbaikan alamiah jaringan-jaringan yang rusak (Morison, 2004 dalam Purwandari dkk, 2014).

Manajemen nyeri merupakan salah satu cara yang digunakan di bidang kesehatan untuk mengatasi nyeri yang dialami oleh pasien. Perawat memberi asuhan keperawatan kepada klien di berbagai situasi dan keadaan yang memberikan intervensi untuk meningkatkan kenyamanan. Kenyamanan merupakan kebutuhan dasar klien yang merupakan tujuan pemberian asuhan keperawatan. Penatalaksanaan nyeri yang tidak adekuat dapat menimbulkan konsekuensi terhadap pasien dan anggota keluarga. Pasien dan keluarga akan merasakan ketidaknyamanan yang meningkatkan respon stres sehingga mempengaruhi kondisi psikologi, emosi, dan kualitas hidup (Ignatavicus \& Workman, 2006 dalam Purwandari dkk, 2014).

Penatalaksanaan nyeri dapat dilakukan dengan teknik farmakologi dan non farmakologi. Pada pasien yang mengalami penanganannya dapat dilakukan dengan teknik non farmakologi. Tindakan non farmakologi diantaranya ialah aromaterapi dengan menggunakan aromaterapi lemon, yang bertujuan untuk melihat pengaruh aromaterapi lemon terhadap intensitas nyeri pasien post operasi laparatomi.

Bau berpengaruh langsung terhadap otak manusia, seperti narkotika. Hidung memiliki kemampuan untuk membedakan lebih dari 100.000 bau yang berbeda yang mempengaruhi manusia tanpa disadari. Bau-bauan tersebut masuk kehidung dan berhubungan dengan silia. Reseptor di silia mengubah bau tersebut menjadi impuls listrik yang di pancarkan ke otak dan mempengaruhi bagian otak yang berkaitan dengan mood (suasana hati), emosi, ingatan, dan pembelajaran (Tara, 2005 dalam Purwandari, 2014).

Menurut Cholifah dkk (2015) dengan judul "Pengaruh Aromaterapi Inhalasi Lemon Terhadap Penurunan Skala Nyeri Persalinan Kala 1 Fase Aktif'. Desain penelitian yang digunakan adalah Quasi Experiment dengan teknik pre-test post-test non equivalent control group design. Hasil penelitian rata-rata nyeri persalinan pada kelompok yang diberikan aromaterapi lebih rendah 4,74 $\pm 1,327$ dibandingkan kelompok kontrol 5,79 $\pm 1,316$. Hasil uji Mann-Whitney $p$ $0,001<0,05$. Variabel luar berpengaruh terhadap nyeri persalinan adalah kecemasan dengan nilai 
$p<0.05$. Aromaterapi inhalasi lemon dapat menurunkan nyeri kala 1 fase aktif.

Aromaterapi lemon merupakan jenis aromaterapi yang dapat digunakan untuk mengatasi nyeri dan cemas. Dari hasil wawancara perawat bahwa penanganan nyeri dilakukan dengan cara farmakologis berupa pemberian analgesic seperti ketorolax, asam traneksamat, asam mefenamat, dan paracetamol dan selain itu juga dilakukan penanganan nyeri secara non farmakologis, jika nyeri dengan skala 1-3. Hasil wawancara dengan pasien, mengatakan mengalami nyeri setelah dilakukan operasi, dan didapatkan data bahwa lima orang pasien tersebut diajarkan oleh perawat dalam mengatasi nyeri menggunakan teknik relaksasi nafas dalam. Sebanyak $60 \%$ pasien mengatakan setelah diajarkan teknik relaksasi nafas dalam skala nyeri berkurang dari skala lima ke empat sedangkan $40 \%$ pasien mengatakan nyeri berkurang dari skala empat ke tiga.

Tujuan penelitian mengetahui pengaruh aromaterapi lemon terhadap penurunan skala nyeri pasien post operasi laparatomi.

\section{METODE}

Jenis penelitian kuantitatif dengan metode penelitian quasy eksperiment menggunakan rancangan One Group Pre-test Post-test. Teknik pengambilan sampel menggunakan purposive sampling.

Populasi penelitian adalah seluruh pasien post operasi laparatomi kedua di Ruangan Rawat inap Bedah di RSUD H. Abdul Moeloek Provinsi Lampung yang berjumlah dalam tiga bulan terakhir adalah sebanyak 54 orang. Kemudian responden yang memenuhi kriteria diperoleh sebanyak 32 orang pasien. Instrumen yang akan digunakan dalam penelitian ini adalah lembar Numeric Rating Scale (NRS) dan observasi (Potter\&Perry). Dan data yang diperoleh diolah menggunakan uji Wilcoxon signed rank test.

Adapun kriteria dalam penetapan sampel adalah sebagai berikut; Post op hari ke 2, berusia 19-45 tahun, pendidikan minimal SD, tidak mengalami gangguan komunikasi dan penciuman, nyeri dengan skala 4-6 (nyeri sedang).

\section{HASIL}

Berdasarkan hasil penelitian diketahui bahwa dari 32 responden, mayoritas responden berumur dewasa akhir (36-45 Tahun) yaitu 19 orang $(59,4 \%)$. Kemudian ditinjau dari jenis kelamin jenis kelamin terbanyak adaah pria dengan jumlah 21 orang $(65,6 \%)$.

\section{Tabel 1. Rata-Rata Skala Nyeri Sebelum dan Sesudah Diberikan Aromaterapi Lemon pada Pasien Post Operasi Laparatomi}

\begin{tabular}{lrrrrr}
\hline & \multicolumn{5}{c}{ Nyeri } \\
\cline { 2 - 6 } $\begin{array}{l}\text { Aroma- } \\
\text { terapi }\end{array}$ & Mean & Med & $\begin{array}{r}\text { Standar } \\
\text { Deviasi }\end{array}$ & $\begin{array}{c}\text { Min- } \\
\text { Max }\end{array}$ & n \\
\hline Sebelum & 5.25 & 5.00 & 0,672 & $4-6$ & 32 \\
\hline Sesudah & 4.00 & 4.00 & 0,718 & $3-5$ & 32 \\
\hline
\end{tabular}

Berdasarkan tabel 1 diketahui bahwa hasil pengukuran rata-rata nyeri pada pasien post operasi laparatomi sebelum diberikan aromaterapi lemon adalah mean 5.25 dengan standar deviasi 0.672 , nyeri terendah adalah 4 dan nyeri tertinggi adalah 6. Pengukuran rata-rata nyeripada pasien post operasi laparatomi sesudah diberikan aromaterapi lemon adalah mean 4.00 dengan standar deviasi 0.718 , nyeri terendah adalah 3 dan nyeri tertinggi adalah 5 .

\begin{tabular}{|c|c|c|c|c|}
\hline $\begin{array}{l}\text { Nyeri } \\
\text { Laparoton } \\
\text { Diberikan }\end{array}$ & $\begin{array}{l}\text { asien } \\
\text { i Sebe } \\
\text { Aroma }\end{array}$ & $\begin{array}{l}\text { Post } \\
\text { um d } \\
\text { rapi I }\end{array}$ & $\begin{array}{r}\begin{array}{r}\text { Op } \\
\text { Sest } \\
\text { Son }\end{array} \\
\end{array}$ & $\begin{array}{l}\text { erasi } \\
\text { udah }\end{array}$ \\
\hline Nyeri & Mean & SD & $\begin{array}{c}p- \\
\text { value }\end{array}$ & n \\
\hline $\begin{array}{l}\text { Sebelum diberikan } \\
\text { aromaterapi lemon }\end{array}$ & 5.25 & 0,672 & \multirow[t]{2}{*}{0,000} & 32 \\
\hline $\begin{array}{l}\text { Setelah diberikan } \\
\text { aromaterapi lemon }\end{array}$ & 4.00 & 0,718 & & \\
\hline
\end{tabular}

Berdasarkan tabel 2 dapat disimpulkan bahwa distribusi rata-rata indeks nyeri post operasi sebelum diberikan aromaterapi lemon adalah 5.25. Pada pengukuran distribusi rata-rata nyeri setelah diberikan aromaterapi lemon didapatkan rata-rata nyeri 4.00. Nilai selisih mean antara nyeri sebelum dan sesudah diberikan aromaterapi lemon adalah 1.25. Hasil ststistik dengan uji Wilcoxon signed rank test didapatkan hasil p-value sebesar $(0,000)<\alpha(0,05)$, hal ini menunjukkan ha diterima yang artinya aromaterapi lemon memiliki pengaruh dalam menurunkan tingkat nyeri pada pasien post operasi laparatomi. 


\section{PEMBAHASAN}

Berdasarkan hasil analisa yang telah dilakukan pada pasien post operasi laparatomi di Ruang Rawat Inap Bedah RSUD Dr. H. Abdul Moeloek Provinsi Lampung didapatkan bahwa responden terbanyak berusia 36-45 tahun yaitu 19 responden $(59,4 \%)$. Menurut Smeltzer dan Bare, (2002) diperkirakan $85 \%$ dewasa tua sedikitnya mempunyai satu masalah kesehatan kronis yang dapat menyebabkan nyeri, usia merupakan variabel penting yang mempengaruhi nyeri. Perbedaan perkembangan, yang ditemukan di antara kelompok usia ini dapat mempengaruhi cara beraeaksi terhadap nyeri, misalnya anakanak dan lansia.

Hal ini berkaitan dengan penelitian Hayati, (2016) yang berjudul pengaruh teknik distraksi dan relaksasi terhadap tingkat nyeri pada pasien post op di rumah sakit Immanuel bandung yang mengatakan bahwa responden yang mengalami nyeri paling banyak berusia dewasa yaitu usia antara 20-29 tahun. Hal ini juga berkaitan dengan penelitian yang dilakukan oleh Adha (2014) yang berjudul faktor-faktor yang berhubungan dengan respon terhadap nyeri pasien post operasi mayor di Irna Bedah RSUP. Dr. Jamil Padang 2014. Menunjukkan ada hubungan umur ( $p$ value $=0,014)$, jenis kelamin $(p$-value $=0,011)$, dengan respon nyeri pasien post operasi mayor di Irna bedah RSUP Dr. Djamil Padang. Pada umur lansia pasien lebih siap melakukan, menerima dampak, efek dan komplikasi tindakan operasi dari pada dewasa. Dalam umur seseorang belum tentu dapat menahan dan menerima suatu tindakan dalam dirinya yang dapat menimbulkan kecacatan pada dirinya.

Menurut analisa peneliti usia dewasa lebih merasakan nyeri daripada lansia hal ini dikarenakan lansia cenderung untuk mengabaikan nyeri dan menahan nyeri yang berat dalam waktu yang lama sebelum melaporkannya atau mencari perawatan kesehatan (Smeltzer \& Bare, 2002).

Menurut Gill, 1990 dalam Potter \& Perry, 2006, secara umum pria dan wanita tidak berbeda secara bermakna dalam berespon terhadap nyeri. Dalam penelitian ini peneliti membagi kelompok usia responden laki-laki dan perempuan menjadi 2 kelompok yaitu kelompok dewasa dan kelompok lansia. Data yang diperoleh peneliti, responden laki-laki dan perempuan tidak memiliki proporsi yang sama, responden laki-laki lebih banyak yang mengalami nyeri dari pada responden perempuan. Namun, skor nyeri responden lakilaki lebih tinggi dari pada responden perempuan.
Menurut Wijaya (2014) intensitas nyeri pasien pasca bedah abdomen pada laki-laki lebih tinggi daripada wanita dengan $p$-value $=0,004$. Menurut analisa peneliti laki-laki lebih responsif terhadap nyeri dari pada perempuan. Perempuan lebih banyak memiliki pengalaman nyeri dari pada laki-laki. Dalam penelitian ini usia perempuan berada pada rentang usia dewasa akhir sehingga kemungkinan sudah pernah melahirkan dan pernah merasakan nyeri yang berat sebelumnya. Berdasarkan tabel 1 diperoleh data rata-rata skala nyeri sebelum diberikan aromaterapi lemon dengan hasil 5,25 dengan standar deviasi 0,672 dan skala nyeri terendah adalah 4 dan skala nyeri tertinggi adalah 6. Dimana 5,20 masuk dalam kategori nyeri sedang (4-6). Nyeri yang dirasakan responden disebabkan karena luka post operasi laparatomi. Keluhan nyeri adalah hal yang paling sering muncul setelah pembedahan. Dalam penatalaksanaan nyeri dapat digunakan teknik farmakologi dan non farmakologi. Perawat di ruangan hanya menggunakan farmakologi. Terapi non farmakologi dapat digunakan untuk membantu menurunkan nyeri secara lebih efektif dan tidak menimbulkan efek samping yang membahayakan. Hasil penelitian ini menunjukkan bahwa tidak ada responden yang tidak mengalami nyeri.

Menurut Potter \& Perry (2006), nyeri adalah keluhan tersering pada pasien setalah mengalami pembedahan. Nyeri yang dialami pasien post operasi muncul disebabkan rangsangan mekanik luka yang menyebabkan tubuh menghasilkan mediator-mediator kimia nyeri sehingga muncul nyeri pada setiap pasien post operasi (Smeltzer \& Bare, 2002).

Faktor yang dapat menyebabkan nilai nyeri berbeda-beda atau bervariasi dan menunjukan perubahan yang relatif kecil, dan reaksi terhadap nyeridipengaruhi oleh berbagai faktor, seperti usia, jenis kelamin, latar belakang sosial budaya, lingkungan, dan pengalaman sensori itu sendiri. Arti nyeri bagi seseorang memiliki banyak perbedaan dan hampir sebagian arti nyeri merupakan arti yang negatif, seperti membahayakan merusak dan lain-lain. Berdasarkan tabel 1 diperoleh data rata-rata skala nyeri sesudah diberikan aromaterapi lemon adalah 4,00 dengan standar deviasi 0,718 dan skala nyeri terendah adalah 3 dan skala nyeri tertinggi adalah 54,00 dengan standar deviasi 0,718 dan skala nyeri terendah adalah 3 dan skala nyeri tertinggi adalah 5. Secara kuantitatif penelitian ini berpengaruh karena menunjukkan adanya perbedaan rata-rata skala nyeri sebelum dan sesudah dilakukan aromaterapi. Rata-rata nyeri berkurang menjadi 4,00 . 
Hal ini sesuai dengan teori Koensoemardiyah (2009) mengungkapkan bahwa teknik pemberian aromaterapi menjadi salah satu alternatif terapi bagi mereka yang sedang mengalami tekanan batin atau stres, dan yang paling penting yaitu untuk menurunkan intensitas nyeri, minyak essensial atau minyak atsiri yang bersifat menurunkan atau menghilangkan rasa nyeri, antara lain: lemon, lavender, cengkeh, dan peppermint, karena terapi dengan menggunakan wewangian dari berbagai jenis tanaman ini bias membuat seseorang menjadi lebih rileks dan tenang. Aromaterapi merupakan suatu metode yang menggunakan minyak atsiri untuk meningkatkan kesehatan fisik dan juga memengaruhi kesehatan emosi seseorang (Koensoemardiyah, 2009).

Menurut analisa peneliti penurunan nyeri yang dialami oleh responden disebabkan oleh pemberin terapi non farmakologi yaitu aromaterapi lemon karena didalam aromaterapi lemon tersebut terdapat zat-zat yang dapat membuat responden menjadi rileks dan tenang, sehingga nyeri yang dirasakan tersebut dapat berkurang. Berdasarkan tabel 2 hasil penelitian ini diperoleh data distribusi rata-rata nyeri sebelum diberikan aromaterapi lemon dengan hasil 5,25, standar deviasi 0,672 , nilai minimum 4, dan nilai maksimum 6. Setelah diberikan aromaterapi lemon tampak adanya penurunan distribusi rata-rata, hasil penelitian ini diperoleh data distribusi rata-raata nyeri responden nyeri setelah diberikan aromaterapi lemon dengan hasil 4,00, standar deviasi 0,718 , nilai minimum 3 dan nilai maksimum 5. Secara kuantitatif penelitian ini bermakna karena menunjukkan adanya perbedaan skor nyeri sebelum dan sesudah diberikan aromaterapi lemon rata-rata nyeri berkurang menjadi 4,00

Hasil analisis bivariat penelitian yang telah dilakukan dengan menggunakan uji Wilcoxon signed rank test diperoleh hasil $(0,000)<\alpha(0,05)$ yang berarti Ho ditolak, sehingga dapat disimpulkan bahwa terdapat perbedaan rata-rata skala nyeri sebelum dan sesudah diberikan aromaterapi lemon pada pasien pasien post operasi laparatomi

Menurut Black dan Hawks (2005), penatalaksanaan nyeri akan lebih efektif jika dikombinasikan dengan terapi non farmakologi. Salah satu terapi non farmakologi yang dapat digunakan yaitu aromaterapi. Aromaterapi merupakan penggunaan ekstrak minyak esensial tumbuhan yang digunakan untuk memperbaiki mood dan kesehatan (Primadiati, 2002 dalam Purwandari dkk, 2014).
Menurut Koensoemardiyah (2009), aromaterapi merupakan suatu metode yang menggunakan minyak atsiri untuk meningkatkan kesehatan fisik dan juga memengaruhi kesehatan emosi seseorang. Teknik pemberian aromaterapi menjadi salah satu alternatif terapi bagi mereka yang sedang mengalami tekanan batin atau stress, dan yang paling penting yaitu untuk menurunkan intensitas nyeri, minyak essensial atau minyak atsiri yang bersifat menurunkan atau menghilangkan rasa nyeri, antara lain: Lemon, lavender, cengkeh, dan peppermint, karena terapi dengan menggunakan wewangian dari berbagai jenis tanaman ini biasa membuat seseorang menjadi lebih rileks dan tenang.

Penelitian ini sejalan dengan penelitian yang dilakukan oleh (Purwandari dkk, 2014) yang berjudul efektivitas aromaterapi lemon terhadap penurunan skala nyeri pada pasien post operasi laparatomi di rumah sakit awal bros dan rumah sakit syafira pekanbaru. Bahwa rata-rata intensitas nyeri post laparatomi sesudah menghirup aroma lemon pada kelompok eksperimen adalah 2,6 dengan standar deviasi 0,737 dan 4,47 pada kelompok kontrol tanpa menghirup aroma lemon dengan standar deviasi 0,915. Melalui uji statistik diperoleh nilai $p(0,000)<\alpha \quad(0,05)$, maka dapat disimpulkan bahwa terdapat perbedaan yang signifikan antara rata-rata skala nyeri sebelum dengan rata-rata nyeri sesudah menghirup aromaterapi lemon pada kelompok eksperimen.

Penelitian lain yang mendukung adalah penelitian yang dilakukan oleh Cholifah dkk (2016), rata-rata nyeri persalinan pada kelompok yang diberikan aromaterapi lebih rendah $4,74 \pm 1,327$ dibandingkan kelompok kontrol 5,79 $\pm 1,316$. Hasil uji Mann-Whitney $p=0,001<0,05$. Variabel luar berpengaruh terhadap nyeri persalinan adalah kecemasan dengan nilai $p<0.05$. Aromaterapi inhalasi lemon dapat menurunkan nyeri kala 1 fase aktif.

Menurut analisa peneliti pasien yang telah menjalani operasi laparatomi akan merasakan nyeri. Hal ini dikarenakan tindakan yang dilakukan adalah dengan cara menyayat lapisanlapisan abdomen lapis demi lapis sehingga menyebabkan nyeri yang dirasakan pasien post operasi laparatomi, dan kurangnya terapi pendamping seperti terapi non farmakologi yang salah satunya adalah pemberian aromaterapi untuk membantu menurunkan tingkat nyeri. Aromaterapi lemon dapat membantu menurunkan skala nyeri yang dirasakan pasien.Pemberian aromaterapi kepada pasien post operasi dapat menurunkan skala nyeri. Hal ini tercantum dalam undang-undang keperawatan 
No.38 tahun 2014 tentang praktik keperawatan pasal 30 ayat (2) huruf $m$ yang berbunyi "dalam menjalankan tugas sebagai pemberi asuhan keperawatan di bidang upaya kesehatan masyarakat, perawat berwenang melakukan penatalaksanaan keperawatan komplementer dan alternatif" dalam penejelasanya pasal 30 ayat (2) huruf $\mathrm{m}$ tersebut adalah melakukan penatalaksanaan keperawatan komplementer dan alternatif merupakan bagian dari penyelenggaraan praktik keperawatan dengan memasukan atau mengintegrasikan terapi komplementer dan alternatif dalam pelaksanaan asuhan keperawatan.

Aromaterapi dapat digunakan dalam intervensi asuhan keperawatan post operasi. Dalam penelitian ini terdapat perbedaan yang cukup signifikan antara nyeri sebelum dan sesudah pemberian aromaterapi lemon. Jika dilihat dari analisa bivariat dapat disimpulkan bahwa terdapat pengaruh pemberian aromaterapi lemon terhadap penurunan nyeri pasien post operasi laparatomi.

\section{DAFTAR PUSTAKA}

Brunner, S., \& Suddarth, D. 2002. Buku Ajar Keperawatan Medikal Bedah. Jakarta: EGC.

Cholifah, S., Raden, A., \& Ismarwati, I. 2016. Pengaruh aromaterapi inhalasi lemon terhadap penurunan nyeri persalinan kala I fase aktif. Jurnal Kebidanan dan Keperawatan Aisyiyah, 12(1), 46-53.

Kartawijaya, Y. 2017. Hubungan antara Karakteristik Demografi dengan Pengetahuan Mobilisasi Dini pada Pasien Post Operasi Laparatomi di RS PKU Muhammadiyah Bantul. https://anzdoc.com/bab-i-pendahuluanperubahan-fisiologis-tubuh-danmempengaruh.html (Diakses pada Februari 2018).

Koensoemardiyah. 2009. A-Z Aromatherapy untuk Kesehatan, Kecantikan, dan Kebugaran. Yogyakarta: Penerbit Andi.

Kozier, Dkk. 2010. Buku Ajar Fundamental Keperawatan: Konsep, Proses \& Praktik, Ed 7, Vol 2. Jakarta: EGC.

Potter \& Perry. 2006. Buku Ajar Fundamental Keperawatan: Konsep, Proses dan Praktik Ed 4, Vol 2. Jakarta: EGC.

\section{SIMPULAN}

Dapat disimpulkan bahwa terdapat perbedaan nyeri sebelum diberikan aromaterapi lemon adalah 5,25 dan setelah diberikan aromaterapi lemon adalah 4,00 dengan $p$ value $(0,000)<\alpha(0,05)$ pada pasien post operasi laparatomi.

\section{SARAN}

Diharapkan agar penatalaksanaan atau manajemen nyeri pada pasien post operasi laporatomi dapat didampingi dengan pemberian aromaterapi lemon, sehingga perlu dibuatkan Standar Operasional Prosedur (SOP) dalam pelaksanaan tindakan aromaterapi lemon ini.

Purwandari, F., \& Sabrian, F. 2012. Efektifitas Terapi Aroma Lemon terhadap Penurunan Skala Nyeri pada Pasien Post Laparatomi. Jurnal Online Mahasiswa Program Studi Ilmu Keperawatan Universitas Riau, 1(1), 1-6.

Sartika, Dewi HB, Suarnianti, S., \& Ismail, I. 2013. Pengaruh Komunikasi Terapeutik Terhadap Tingkat Kecemasan pada Pasien Pre Operasi di Ruang Perawatan Bedah RSUD Kota Makassar Tahun 2013. Jurnal Ilmiah Kesehatan Diagnosis, 3(3), 18-22.

Sjamsuhidajat, R. W. D. J., \& De Jong, W. 2005. Buku Ajar Ilmu Bedah. Jakarta: EGC.

Smeltzer, Suzanna C dan Bare, Brande G. 2002. Buku Ajaran Keperawatan Medikal Bedah Edisi 8, Vol 1, Buku Kedokteran. Jakarta: EGC.

Wijaya, I. P. A. 2014. Analisis Faktor-faktor Yang Mempengaruhi Intensitas Nyeri Pasien Pasca Bedah Abdomen Dalam Konteks Asuhan Keperawatan di RSUD. Badung Bali. Jurnal Dunia Kesehatan, 5(1). 